\title{
CINISMO E ESTÉTICA DA EXISTÊNCIA EM FOUCAULT: A INTERPELAÇÃO DOS ANTIGOS À INSTITUIÇÃO ESCOLAR
}

\author{
Jonas Rangel de Almeida. Mestrado PPGE/ UNESP - Marília. Bolsista CAPES. \\ Orientador: Prof. Dr. Pedro Ângelo Pagni. \\ EMAIL: jradavisao@yahoo.com.br
}

\section{RESUMO:}

Este trabalho apresenta resultados parciais de pesquisa empreendidos no campo da Filosofia da Educação. O objetivo é discutir quais os desafios que a arte de viver dos cínicos pode trazer aos educadores e à instituição escolar. $\mathrm{O}$ cinismo, entendido como um modo de vida, ocupa um lugar importante na última palestra de Michel Foucault no Collège de France em 1984. O filosofo francês considera esse movimento como uma filosofia de dizer a verdade parrhésia - e, uma maneira escandalosa de viver. Segundo Foucault, essa tékhne tou bíou compreende elementos importantes de uma estética da existência na qual o sujeito realiza uma transformação de si por si mesmo. Tal modificação pressupõe uma interpelação para o outro chamando também a se transformar e viver uma vida outra. Essa provocação cínica traz algumas correspondências com nossa atualidade bem acentuadas por Foucault nos modos de vida revolucionários do século XIX. No contexto atual onde a relação educativa está sujeita a um regime de verdade que garante o acesso à verdade ao sujeito por meio da aquisição da lei, da adaptação à norma e pela internalização de um código moral - identitário - o cinismo traz uma interpelação quanto à maneira de viver a vida, de dizer a verdade ainda que esta lhe coloque em risco e uma atitude ética de resistência ao discurso que anula as diferenças. $\mathrm{O}$ legado cínico convida os educadores do tempo presente a educar para novos modos de vida e reaproximar a escola da vida.

Palavras-chave: Cinismo, estética da existência, arte de viver e instituição escolar.

\section{INTRODUÇÃO.}

Este trabalho procura apresentar resultados parciais de pesquisa empreendidos no campo da Filosofia da Educação. O objetivo é discutir de que modo à interpelação da arte de viver na cultura antiga, em particular do movimento cínico, pode desafiar os educadores do tempo presente e à instituição escolar. Neste sentido, a direção a seguir será de introduzir elementos de tensão e ensaiar caminhos possíveis de serem trilhados como uma possível resposta a questão: como o discurso filosófico pode contribuir para com a formação ética do professor? Afinal, qual o máximo de intensidade filosófica e quais os efeitos filosóficos atuais que 
podem ser extraídos do cinismo? Por meio desta análise pretende-se problematizar como os exercícios de si sobre si podem concorrer para a reativação de um ethos, na instauração de uma cultura de atitude, que venha suprir o déficit na formação de intelectual e no seu ofício de educador.

Segundo Castro (2009), todo o percurso intelectual de Foucault nos fins da década de 1970 e inicio de 1980 constitui um esforço de superar os impasses da analítica do poder. Dificuldade criada justamente pela hipótese da resistência. A acusação de certa impotência diante das relações de poder microfísicas levou Foucault a elaborar a noção de governo dos homens e traçar uma história das práticas de subjetivação do ocidente. De acordo com Castro (2009), pode-se dizer que o interesse de Foucault se desloca do eixo do saber e poder para o eixo da ética. Esse deslocamento corresponderia aos corriqueiramente chamados três períodos do seu trabalho: arqueologia, genealogia e ética; e, às noções: episteme, dispositivos e práticas. Esses deslocamentos devem ser compreendidos como uma extensão dos domínios de análise e não como negação. Com efeito, a genealogia não abandona o estudo das formas de saber, tampouco, o estudo da ética os dispositivos de poder, pois, a noção de dispositivo comporta a de episteme, do mesmo modo que a de prática compreende a de dispositivos de saber/poder. A genealogia da ética procura articular ética e política.

Segundo Foucault (1995) a constituição das subjetividades desde sempre foi o tema central de sua obra filosófica. Tal constituição, por sua vez, está sempre em transformação através de dois processos: objetivação e subjetivação. A objetivação ocorre de modo duplo. De um lado, uma objetivação no qual o homem - figura discursiva que tem pretensão de universalidade - passa a ser o objeto da ciência, chamado terreno arqueológico. De outro, por meio das práticas divisórias, as relações poder/saber, o terreno genealógico. Já o domínio da subjetivação, isto é, os modos através da qual os indivíduos se reconhecem como sujeitos em uma cultura, ocorrem no entrecruzamento de estratégias de governo e tecnologias de si.

Na entrevista $O$ Sujeito e o Poder (1983), Foucault explícita os objetivos de suas analises dizendo:

Eu gostaria de dizer, antes de mais nada, qual foi o objetivo do meu trabalho nos últimos vinte anos. Não foi analisar o fenômeno do poder nem elaborar os fundamentos de tal análise. Meu objetivo, ao contrário, foi criar uma história dos diferentes modos pelos quais, em nossa cultura, os seres humanos tornaram-se sujeitos. (FOUCAULT, 1995, pg. 231-232).

Diante desse pronunciamento de Foucault a interpelação central deste trabalho é: os contemporâneos são capazes de realizar experiências de si sobre si à maneira dos antigos 
como enuncia Foucault? Através de quais práticas nos reconhecemos enquanto sujeitos em nossa cultura? A hipótese deste trabalho é que se constituindo como um potente dispositivo de subjetivação (LAROSSA, 2002), a linguagem e o discurso filosófico podem interpelar o sujeito quanto a sua postura diante do ensino, da política, dos acontecimentos e da vida provocando inclusive os educadores a reinventarem a si mesmos favorecendo a geração de novos estilos de existência. Devido à limitação de tempo e espaço para desenvolvermos a análise apresentaremos a seguir uma parte do texto integral. Em especial, destacaremos a leitura que Foucault faz do cinismo em seus últimos cursos mostrando de que maneira tal escola compreende elementos importantes de uma estética da existência na qual o sujeito realiza uma transformação de si por si mesmo. As últimas investigações de Foucault no Collège de France consideram esta escola como uma filosofia de dizer a verdade - parrhésia e, uma maneira escandalosa de viver estabelecendo importantes modalidades de exercícios que ligam a constituição do sujeito ao dizer verdadeiro.

É necessário mencionar que a noção de interpelação é inspirada no trabalho desenvolvido na década de 1960, pelo filósofo marxista Louis Althusser (1985) que dizia que toda ideologia interpela os indivíduos concretos em sujeitos concretos. Para Althusser (1985, p. 93) a ideologia funciona de tal forma que ela recruta sujeitos dentre os indivíduos e através dessa operação precisa, que se chama interpelação. Este mecanismo deve ser entendido através dos tipos mais banais de perguntas, como a de um policial "ei você ai? ou !", ou, quando um amigo bate a nossa porta e perguntamos "quem é?" e recebemos uma resposta evidente "sou eu". Por essa simples conversão física a $180^{\circ}$, ele se torna sujeito. Por quê? Porque reconheceu que a interpelação de fato se dirigia para ele e era ele em particular que era interpelado e não outro. A ideologia interpela o individuo em sujeito antes de ele nascer. Com efeito, o caso concreto é que quando reconhecemos a interpelação do policial e nos viramos, ou, quando um amigo nos responde, o ritual de interpelação opera transformando os indivíduos concretos sempre-já em um sujeito concreto. Althusser lembra que a palavra sujeito (sujet) em francês têm dois sentidos: é ao mesmo tempo, uma subjetividade livre, um centro de inciativas, autor e responsável por seus atos e um ser submetido, assujeitado a autoridade superior, logo desprovido de toda liberdade, exceto de aceitar livremente sua sujeição. Finalmente, ao ser questionado sobre a noção de sujeito Foucault (1995) se aproxima muito da cunhada por Althusser:“[...] sujeito a alguém pelo controle e dependência, e preso à sua própria identidade por uma consciência ou autoconhecimento" (p.235). Deleuze (2005), interpretando Foucault, diz que a luta por uma subjetividade moderna passa pela 
resistência de duas formas de sujeição, uma contra a individualização que o poder exige e a outra contra a identidade determinada de uma vez por todas, portanto, que "[...] se apresenta então como direito à diferença e direito à variação, a metamorfose" (2005 p.113). Diferentemente de Althusser, Foucault não analisa o problema da interpelação do sujeito através do conceito de ideologia ${ }^{\mathrm{i}}$, mas, entende o problema em termos de verdade e poder. Diz Foucault (2008, p.14):

O problema político essencial para o intelectual não é criticar os conteúdos ideológicos que estariam ligados à ciência ou fazer com que sua prática científica seja acompanhada por uma ideologia justa; mas saber se é possível constituir uma nova política da verdade. O problema não é mudar a consciência das pessoas, ou o que elas têm na cabeça, mas o regime político, econômico, institucional de produção da verdade.

Segundo Foucault (1995), podemos reconhecer três formas principais de lutas históricas: lutas contra as dominações (políticas); lutas contra as explorações (econômicas); lutas contra as sujeições (éticas). Elas atravessam toda a história. Mas, depois de meados do século XX a última luta, contra a sujeição da subjetividade tem adquirido preponderância. $\mathrm{O}$ principal objetivo dessa luta não está em atacar tanto uma ou outra instituição de poder, grupo, classe, elite, quanto uma técnica particular, uma forma de poder. E sim, resistir a despeito da forma de poder que se exerce sobre a vida cotidiana das pessoas, que classifica os indivíduos em categorias, designa-os por sua individualidade própria, prende-os à sua identidade, impõe-lhes uma lei de verdade que é preciso neles reconhecer. É precisamente contra esta forma de poder que transforma os indivíduos em sujeitos, contra está tecnologia de sujeição que é preciso se liberar dos seus efeitos e do tipo de individualização que promove, é uma luta contra essa forma de subjetividade que foi imposta há séculos, uma luta por novas formas de subjetivação. Tais lutas questionam o próprio estatuto desse sujeito assujeitado pelo direito à diferença.

Segundo Gros (2006) o Estado, cuja genealogia para nossas sociedades modernas ele procurou traçar a proveniência de 1976 a 1979, apresenta-se como simultaneamente totalizante e individualizante. O Estado com todos os seus dispositivos, sejam eles, pastorais, de segurança e de vigilância dos indivíduos e das populações não consiste em outra coisa senão uma maneira de governar. Sob essa perspectiva, segundo Foucault (2008), o grande problema é entender em que momento, e sob que condições e formas o Estado começou a ser projetado, programado e desenvolvido no interior da prática consciente das pessoas, quando esse se tornou um objeto de conhecimento e de análise, como ele entrou numa estratégia meditada e concertada, por que o Estado passou a ser invocado, desejado, cobiçado, temido, 
repelido, amado, odiado pelos homens. Como se deu essa entrada do Estado no campo da prática e do pensamento dos homens.

Segundo Gros (2006, p. 659), pode-se observar nessas lutas a dimensão individualizante do poder pastoral. É preciso se liberar do Estado e do tipo de individualização que a ele se vincula. Devem-se promover novas formas de subjetividade. Para Gros (2006, p. 659) é a partir dos anos 1980 que Foucault determinará com clareza o que se deve opor ao Estado, em seus propósitos gestores e normalizadores, individualizantes e identificadores. Trata-se precisamente das práticas de si, tomadas na dimensão relacional, na eleição dos modos de vida, na construção da estilística da existência.

As últimas problematizações de Foucault se separavam nitidamente do então formulado projeto dos anos setenta, da história da produção das subjetividades assujeitadas, dos procedimentos de sujeição pelas máquinas do poder, pois, nesse ultimo esforço analítico se trata de determinar o modo de subjetivação ao invés da de definir seu modo de objetivação. Nessa época o autor passa a trabalhar com a Grécia fundando seu pensamento na possibilidade ética - de que é possível moldar a própria subjetividade através de um trabalho de si sobre si. Para analisar de forma mais detalhada o desenvolvimento das técnicas de si, este autor reportou seu olhar à antiguidade tardia e para cultura greco-romana mostrando que à preocupação consigo mesmo se constituía um dos princípios de maior significação para as atividades políticas. O preceito grego epimeleia heautou, a cura sui, isto é, "tomar conta de si” (FOUCAULT, 1990, p.50), se configura um dos grandes princípios das cidades, uma das grandes regras de conduta da vida social e pessoal, um dos fundamentos da arte de viver. Desse modo, Foucault passa a escrever um audacioso projeto da história dos processos de subjetivação que tem como eixo principal as práticas de si, ou, os exercícios espirituais. E ao contrário de um historiador que olha para o passado longínquo, Foucault se interessa em analisar como esses processos têm seus efeitos no presente. Seu objetivo é explorar maneiras de gerar novos estilos de vida, de reinventar a si mesmo e se desprender dos modos de ser nos legados pela história, ou, imposto pelas estruturas sociais, nomeando esse esforço como uma estética da existência.

Segundo Gros (2011, p. 310), poucos documentos do movimento cínico nos restaram, tal fato deve-se, por um lado, ao conteúdo doutrinal que era relativamente grosseiro esboçado pelos filósofos dessa escola e, por outro, pelo descuido que tiveram com a arte de escrever. Somando esses fatores com a interpretação minimalista que receberam de importantes historiadores da filosofia, como Hadot (1999) e Bréhier (1956), torna-se 
perceptível o porquê da marginalidade dessa escola. Segundo Gros (2011), partindo dessa indigência teórica, Foucault reporta o cinismo para fazer dele o momento puro de reavaliação radical da verdade filosófica, ressituada no campo da práxis, da prova de vida, da transformação do mundo.

$\mathrm{Na}$ perspectiva do especialista em cultura antiga Pierre Hadot a filosofia durante muito tempo foi entendida como uma maneira de viver. Esta consistia em uma série de exercícios espirituais que visavam preparar o indivíduo para a vida. Segundo Hadot (2008) intitula-se como exercício espiritual um conjunto de práticas ordinárias, fórmulas, e um discurso interior que mudam a disposição do indivíduo, formando suas posturas diante da vida elevando-o a uma integração cósmica. Ao contrário da teoria abstrata e do discurso exterior na qual se tornou a filosofia moderna e seu ensino, os exercícios espirituais mantém uma relação íntima com a vida filosófica. Para Hadot (2008) os exercícios espirituais precisam ser interiorizados, eles suscitam a dúvida e exigem ascese, isto é, a obrigação de se submeter a determinadas regras e critérios para alcançar eficácia. Na acepção de Hadot, a ideia de que o indivíduo é uma fabricação nos deixa a consequência prática de criar a nós mesmos como uma obra de arte. Inspirando-se na leitura dos exercícios espirituais de Pierre Hadot, Michel Foucault, em seu percurso tardio, revisitará a cultura antiga para se interrogar sobre a atualidade dos modos de existência no presente.

Segundo Hadot (1999, p. 162) o modo de vida cínico opõem-se de maneira radical com a dos não-filósofos, mas, também com a de outros filósofos. A ruptura do cínico com o mundo é radical. Ele rejeita aquelas as regras que os homens consideram elementares, as condições indispensáveis de vida em sociedade: a propriedade, o governo e a política. Diógenes despreza os convencionalismos da sociedade, ele pratica o impudor deliberado masturbando-se em público. O cínico despreza o dinheiro, apenas lembrando a expressão utilizada por Bréhier de adulterar a moeda, além disso, não hesita em mendigar quando sente fome, ou pedir abrigo quando sente frio. Ele não procura uma vida estável, evita adquirir matrimônio, contentando-se em ter em seu alforje tão somente o necessário para sua sobrevivência. Diz Hadot “[...] Não teme as autoridades e exprime-se em todos os lugares com uma provocadora liberdade de expressão (parrhesia)" (1999, p. 163).

Por esses fatores existe entre os historiadores uma enorme dificuldade em determinar se o cinismo é realmente uma escola filosófica, ou, apenas um modo de vida. Segundo Hadot (1999) apesar desses elementos problemáticos os cínicos formam uma escola na medida em que se pode reconhecer entre eles uma relação entre mestre e discípulo. Hadot 
(1999) ressalta um episódio simbólico pode nos ajudar a pensar essa questão. Uma pessoa afirma para Diógenes que o movimento cínico não existe, ele simplesmente fica de pé anda. Nesse sentido, o cinismo é unicamente uma escolha de vida e de liberdade em prol de total independência (autarkeia) diante das necessidades inúteis, a recusa do luxo e da vaidade (typhos). Sem dúvida existem conceitos cínicos, mas, eles não devem ser considerados como uma argumentação lógica e sim para designar atitudes concretas: a ascese, a ataraxia (ausência de perturbação), a autarquia (independência), o esforço, a adaptação às circunstâncias, a impassibilidade, a simplicidade e o impudor. A escolha do gênero de vida do cínico se da por considerar que o estado de natureza (physis), tal qual se pode reconhecer no comportamento do animal ou da criança. A filosofia cínica se baseia totalmente na ascese (exercícios), tais escolhas não são especulações teóricas, mas, questões ligadas à vida. Nesse sentido, o modo de vida cínico consistira num esforço atlético para suportar a fome, a sede, as intempéries, uma preparação refletida para adquirir mais liberdade, independência, força interior, a ausência de cuidados e a tranquilidade de uma alma capaz de se adaptar a todas as circunstâncias.

O tratamento que Hadot (1999) dá ao cinismo, apesar, do mérito retomá-lo como um modo de vida ainda é marginal. Na verdade, a escola cínica é marginal. Se de um lado Bréhier (1956) sustenta sua interpretação ignorando temas como o do cuidado de si e da parrhésia entre os cínicos, por outro, Hadot, para minorar a importância dessa escola, diz que Diógenes não seria nada além de um Sócrates mendigando. Refletindo sobre uma suposta afirmação de Platão sobre Diógenes como um "Sócrates enlouquecido". Para Hadot:

Outro Sócrates que, ele também, se considera investido de uma missão, fazer com que os homens reflitam, denunciar, por seus ataques mordazes e por seu modo de vida, os vícios e os erros. Seu cuidado de si é, indissoluvelmente, um cuidado dos outros. Mas se o cuidado de socrático, ao fazer chegar à liberdade interior, dissolve a ilusão das aparências e das falsas semelhanças ligadas às convenções sociais, preserva sempre certa urbanidade sorridente que desaparece em Diógenes e nos cínicos. (1999, p. 165).

Talvez haja algo de revolucionário nessa marginalidade cínica que deva ser elucidado. A recusa das convenções sociais; o apelo ao natural; o desprezo pelo dinheiro; e, ao luxo. Nos termos de Hadot (1999) da denúncia dos erros dos homens em prol de uma liberdade de expressão (parrhésia).

\section{CONSIDERAÇÕES FINAIS.}


Tal inversão proporcionada pelo pensamento de Foucault redireciona o ensino e explicitação do discurso filosófico em direção a uma experimentação. A intensidade aqui passa pela dimensão corporal, das paixões, dos prazeres e afeta a própria subjetividade do ouvinte. Nesse registro, a filosofia deixa de ser um discurso exterior que privilegia apenas a apreensão correta das proposições e passa a ter um papel formador diante dos acontecimentos imprevisíveis da existência. A vivência no modo de vida não é mais o conhecimento das regras de conduta, ou, um experimento moral, ela começa a ser pensada como um fazer ato de resistência à sujeição das máquinas de poder e a própria normatividade da instituição escolar e das instâncias do Estado. Em tempos modernos, quando a filosofia se converteu em uma disciplina universitária. Quando seu discurso oferece ao mundo apenas interpretações sobre o real, torna-se imprescindível a reativação permanente do ethos filosóficos, nos termos do cuidado de si de Foucault, que nos permite diagnosticar fraturas no presente abrindo espaços para a respiração. O professor completamente sujeito a tutela do Estado na atual conjuntura política exige resistência. E esta, não pode acontecer se ficarmos presos à imagem dogmática da filosofia como explicitação do discurso no que ele tem de estrutura de comportamento. Faz-se necessário, ultrapassar esse limite e remeter a filosofia como uma arte da existência.

\section{REFERÊNCIAS:}

ALTHUSSER, L. Aparelhos ideológicos de Estado: notas sobre aparelhos ideológicos de Estado. 2ed. Rio de Janeiro: Edições Graal, 1985.

BRÉHIER, E. Historia de la filosofia. Tomo primeiro. Buenos Aires: Editorial Sudamericana, 1956.

CASTRO, E. Vocabulário Michel Foucault. Belo Horizonte: Autêntica, 2009.

DELEUZE, G. Foucault. São Paulo: Brasiliense, 1988.

FOUCAULT, M. A hermenêutica do sujeito. São Paulo: Martins Fontes, 2006.

FOUCAULT, M. O sujeito e o poder. In: DREYFUS, H. \& RABINOW, P. Michel Foucault, uma trajetória filosófica: para além do estruturalismo e da hermenêutica. Rio de Janeiro: Forense Universitária, 1995.

FOUCAULT, M. Verdade e poder. In: MACHADO, R. (org.). Microfísica do poder. São Paulo: Editora Graal, 2008.

GROS, F. Situação do curso. In: FOUCAULT, M. A hermenêutica do sujeito. São Paulo, Martins Fontes, 2006.

HADOT, P. O que é a filosofia antiga. São Paulo: Loyola, 1999. 
LARROSA, J. Notas sobre a experiência e o saber da experiência. Revista Brasileira de Educação, Rio de Janeiro, $\mathrm{n}^{\circ} 19$ p. 20-28, jan. /abr. 2002.

\footnotetext{
' Foucault desconfia do conceito de ideologia, apontando três fatores problemáticos para o uso deste conceito: a) "queira-se ou não, ela está sempre em oposição virtual a alguma coisa que seria a verdade" (FOUCAULT, 2008, p. 7). Para Foucault o problema não era "de se fazer a partilha entre o que num discurso releva da cientificidade e da verdade e o que relevaria de outra coisa; mas de ver historicamente como se produzem efeitos de verdade no interior de discursos que não são em si nem verdadeiros nem falsos" (FOUCAULT, 2008, p. 7); b) a ideologia como falsa consciência refere-se necessariamente a um sujeito; c) existe sempre implicado nesta noção a oposição binária entre infra-estrutura e superestrutura, sendo a consciência sempre determinada pelas condições econômicas de existência (FOUCAULT, 2008, p. 7).
} 